\title{
Analysis of Educational Spaces Design Methods for Educable Mentally Disable Children
}

\section{A Case study on 6-17 years old childrens}

\author{
Seyedeh Marzieh Tabaeian ${ }^{1}$, Neda Abbasi Kerdabadi ${ }^{2}$, Ahmad Abedi ${ }^{3}$ \\ 1Islamic Azad University Harand Branch, Isfahan, Iran, marzieh.tabaeian1@gmail.com \\ 2Islamic Azad University Khorasgan Branch, Isfahan, Iran, nabasii@outlook.com \\ 3University of Isfahan, Iran, a.abedi@edu.ui.ac.ir \\ doi.org/10.29080/eija.v4i2.324
}

\begin{abstract}
This study aims to investigate and analyse design and optimisation methods of educational and recreational environments for educable mentally disabled children. This study is conducted using a descriptiveanalytical method based on library research, documents and field surveys. The research studied sixty mentally disabled children aged 6-17 years, twenty instructors and sixty mothers through purposive sampling. Then the quantitative data of questionnaires and the qualitative data of interviews and paintings are analysed using SPSS and Excel. The results of this research determine the useful criteria used to design an attractive and friendly environment for mentally disabled children. In addition to promoting the sense of safety and security in these spaces, it improves recreational activities of mentally disabled children both individually and collectively.
\end{abstract}

Keywords: environmental psychology, architectural design, educational spaces, mentally disable children

Abstrak: Penelitian ini bertujuan untuk menganalisis desain serta metode optimasi lingkungan pendidikan dan rekreasi untuk anak didik dengan disabilitas intelektual. Penelitian ini dilakukan menggunakan metode deskriptifanalitis berdasarkan penelitian literatur, dokumen dan survei lapangan. Sejumlah enampuluh anak dengan disabilitas intelektual berusia 6-17 tahun, duapuluh instruktur dan enampuluh ibu menjadi narasumber penelitian melalui pengambilan sampel secara purposif. Data kuantitatif kuesioner dan data kualitatif wawancara dan hasil gambaran dianalisis dengan bantuan piranti lunak SPSS dan Excel. Hasil penelitian ini menentukan kriteria efektif yang digunakan untuk merancang lingkungan yang menarik dan ramah untuk anak-anak yang mengalami disabilitas intelektualitas. Selain meningkatkan rasa aman dan keamanan di ruangan-ruangan ini, kriteria-kriteria tersebut mampu meningkatkan aktivitas rekreasi anak dengan disabilitas intelektual baik secara individu maupun kolektif.

Kata Kunci: psikologi lingkungan, perancangan arsitektur, ruang pendidikan, anak dengan disabiltas intelektual

\section{INTRODUCTION}

The human and environment relationships have been an inevitable long-standing part of architectural research (Mostafa, 2008). Various studies have shown that the quality of the situation where the person works, e.g. space, colour, light, sound and contentment, affects his perception. Hence the mutual relationship of architecture and psychology is necessary to better design spaces (Tabaian, 2014). Architecture, as a profession, is responsible for creating environments that are compatible with a variety of user needs. The particular people should not be excluded in this regard. There are always people with special needs in the community, e.g. the deaf, blind and those with other psychological and physical disorders. These people are a part of society and require the services and attention as much as others need. Accordingly, people with autistic spectrum disorders are identified as those with special needs that require consideration. The child learns and understands his environment according to his individual needs and competencies. The research obtained environmental information through perceptual processes which are driven by the mental schema and guided by human needs (Lang, 1987).

According to the fifth edition of Diagnostic and Statistical Manual of Mental Disorders (DSM-IV), intellectual disability (ID) is introduced by three general criteria including defective mental functions, difficulties in adaptive performance in terms of conceptual, social and practical aspects and problems during the developmental period (Cabarcas, Espinosa, \& Velasco, 2013). Intellectual disability is a disorder characterised by clear limitations to intelligent and adaptive behaviour (Vargo, 2015). According to the 
DSM-IV, about $1 \%$ of the population has mental disabilities, and its prevalence rate is a function of age and varies according to it (Ganji, 2013). In Iran, 2800000-8400000 people having a disability (Abbasi et al., 2011), of which 28795 have mental disabilities (M Alagheband et al., 2011). Despite the high prevalence of mental retardation in Iran, architectural design strategies have not been specifically addressed to meet the needs of this group. Mentally disabled children and adults are generally disregarded by the community of architects (Fig. 1), and the architects must be familiar with the morale and needs of these people and attempt to create ideal environments for them.

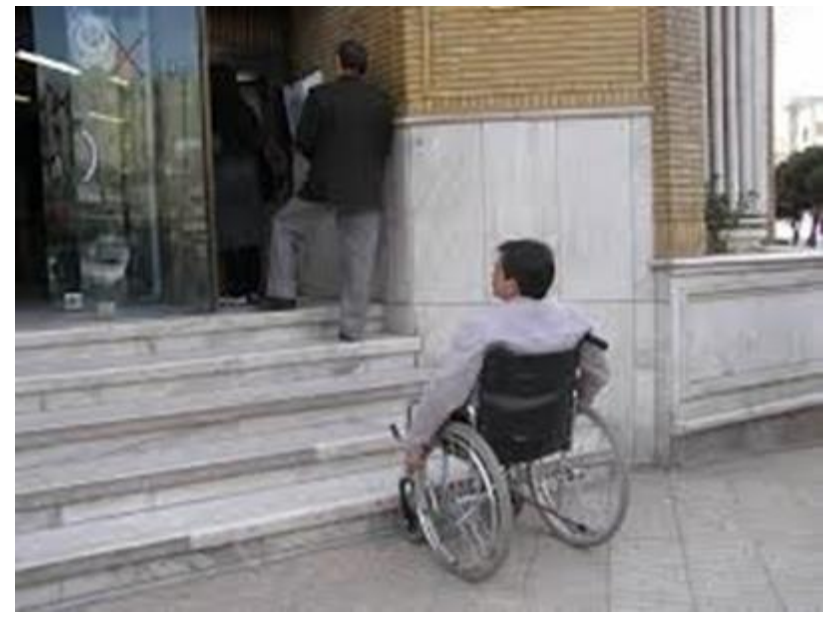

Figure 1. Ignorance of disables accessibility needs in architectural design in Iran.

Today, there are many rehabilitation and educational centres for mentally disabled children in the world that have been established to improve them. The Friendship Circle is located in the west of Bloomfield, Michigan, USA. It provides services for social skills, daily camping and staying overnight, baseball and cycling training, etc. for children with special needs. The Friendship Circle offers over 40 programs designed to develop social, physical and constructive skills of the children. Brown School is located in Pinetown residential area. Pinetown is a location between Kloof and Westville, from which takes 10 minutes to reach the city centre. It is an industrial area, but there are residential houses there, and now it is one of the most critical areas in Durban. The school is enormous and arranged in such a way that classrooms are connected through long corridors, resulting in excessive circulation. There is a wide range of sports facilities, such as cricket, basketball and tennis courts, all of which are used most of the time and this is an important issue. In general, classrooms are large and benefit from good lighting, in addition to the porches used by trainers. Girih tiles are used extensively in the facades, and the texture of bricks is tangible by touching, referring to the spatial readability. It generally seems that the school possesses enough space for all children, although a vast area of the site cannot be used due to the separation of sports spaces from other parts of the school (Tabaian et al., 2015).

Open Air School is a particular school for children with various types of disability, e.g. the blind, deaf and autistic. This place serves 260 elementary students up to the age 13 with a variety of activities for children. The school is located within an open space on the outskirts of Glenwood, Durban, under control Glenwood High School and Glenwood Elementary School. The school is located on a great site; it also offers several sports facilities in cooperation with other schools. There is a parking area outside the school for parents to take their children, but it is not big enough to lead wheelchairs from the street to school. There is a sizeable inviting facade indicating the entry into the school.

However, there has not been constructed any educational-recreational centre for mentally disabled children Iran. According to the information provided by Iranian Department of Education, there are only three camps for mentally disabled children (in Mashhad, Hamedan and Chamestan), where no educational services are offered and are used just as accommodation for these children and their families. Thus the central question of this study is that which design criteria can lead to an attractive and friendly environment for the education of mentally disabled children to promote the educational and cultural activities of this group. Since these children have different needs, their educational environments also involve a particular design.

\section{RESEARCH METHOD}

Hence the study is applied research based on its objective. On the other hand, a descriptive-analytical method is employed because the research process describes the characteristics of mentally disabled children and applies their views and participation to facilitate decision making and present the final model. Quantitative data (questionnaires) and qualitative (paintings, interviews and observations) are used in this study. It should be noted that the quantitative data is collected through survey and cross-sectional research in this study. Since the collected questionnaires attempt to assess current conditions, the samples are taken from the population in a specific period. Since the qualitative data, especially children's paintings, represent their thoughts, behaviours and feelings and the researcher attempts to interpret and codify the desirable behaviours of children in the cultural-recreational environment, the qualitativephenomenological nature of the research is also essential. The statistical population is selected from 7- 
15-year-old children and their teachers and educators through the purposive sampling strategy. Moreover, the teachers and educators are also chosen through purposive sampling, since it is aimed to provide the same environment for the child and teacher (as an expert) and their interaction.

The information is collected through library and field research in this study. In the library research, documents and sources such as Persian and Latin books and articles are referred for initial investigations and examination of the experts' views on children and their educational-playing spaces, resulting in studies about the characteristics of mentally disabled children, the causes of this disorder and research on educational-recreational areas for these children. In this method, the primary data were collected at first and then categorised and used indirectly. In the field research, the researcher attempts to collect information through observations, paintings, interviews and questionnaires. In a direct view, the researcher initially observes, records and takes photos of the children's behaviour in cultural-educational spaces by visiting the internal samples (Farshchian Primary School and Behesht Association for Children in two branches). Then, the children's response is observed and recorded during playing (break time). Given that children's participation, attitudes and interests are the priorities that must be concerned in the design of spaces for children, their paintings are investigated in this study; so pictures of two topics (1. free subject, 2. purposive subject) are collected. A questionnaire (including ten questions, 60 parents) is prepared for obtaining information from teachers and mothers of these children.

The field research is conducted in schools and associations which support these children. Therefore, Farshchian Primary School for girls and Behesht Association for Children are selected to do these studies. The research takes 45 minutes for every six students on morning shift for three days. According to the research method, the necessary explanations are provided based on the purpose of this study before giving A4 sheets to the children and questionnaires to the mothers and teachers. Teachers are also advised to respond to questions about their school conditions realistically, and the children are also asked to paint their favourite space. Various accessories (colour pencils and pastels) are provided for children to have no restriction for painting. After collecting the paintings, each child is asked to give explanations about his/her painting details, and the researcher takes note and records the keywords. A survey is also conducted among children about the album (samples taken from cultural-educational centres). In the present study, the qualitative data is analysed using descriptive statistics.

\section{RESULT AND DISCUSSION}

\subsection{Observation Result}

This study aims to achieve the principles and rules to design educational environments for mentally disabled children and improve the quality and efficiency of such spaces. The qualitative data and research findings, including interviews and paintings, are presented in Table 1 using a descriptive approach

Table 1. The desirable spaces from children's point of view.

\begin{tabular}{ll}
\hline $\begin{array}{l}\text { Furniture for } \\
\text { children }\end{array}$ & In children's spaces, furniture should be lightweight, portable, soft and comfortable. \\
\hline Adults' accessories & $\begin{array}{l}\text { Attention to small-scale devices and materials resembling adults' jobs can be useful to discover } \\
\text { their potentials, e.g. small-scale kitchen, soft and lightweight construction materials, guide signs, } \\
\text { etc. }\end{array}$ \\
\hline $\begin{array}{l}\text { Pictures, books, } \\
\text { bookcases }\end{array}$ & A bookcase especial for children may provide a calm environment to read stories. \\
\hline View of windows & $\begin{array}{l}\text { Visual connection of spaces and the interaction of the inside and outside is attractive for } \\
\text { children. }\end{array}$ \\
\hline Nature & $\begin{array}{l}\text { Children are interested and its fantastic elements and like playing beside plants, flowers, } \\
\text { animals, etc. }\end{array}$ \\
\hline Inviting entrances & $\begin{array}{l}\text { Walking paths and lines inside the site make children aware of entries, which is affected by the } \\
\text { use of colours and glorious decorations. }\end{array}$ \\
\hline Lighting & $\begin{array}{l}\text { Natural daylighting and transparency have positive impacts on children. So corridors and even } \\
\text { small or trivial spaces must enjoy daylighting to prevent scary scenes. }\end{array}$ \\
\hline Comfort & $\begin{array}{l}\text { The child's comfort results from the satisfaction of his/her need in the space. Therefore, children } \\
\text { prefer classrooms with shelves and niches, windows protruding toward the outside nature, } \\
\text { smooth flooring, comfortable sofas, wood furniture and soft sunlight. }\end{array}$ \\
\hline Colourfulness & \begin{tabular}{l} 
Children like bright and vibrant colours, striped patterns and bright spots. \\
\hline
\end{tabular}
\end{tabular}

Source: analysis result, 2017 
The quantitative data and research findings, including questionnaires, are presented in Charts 1 to 4 .

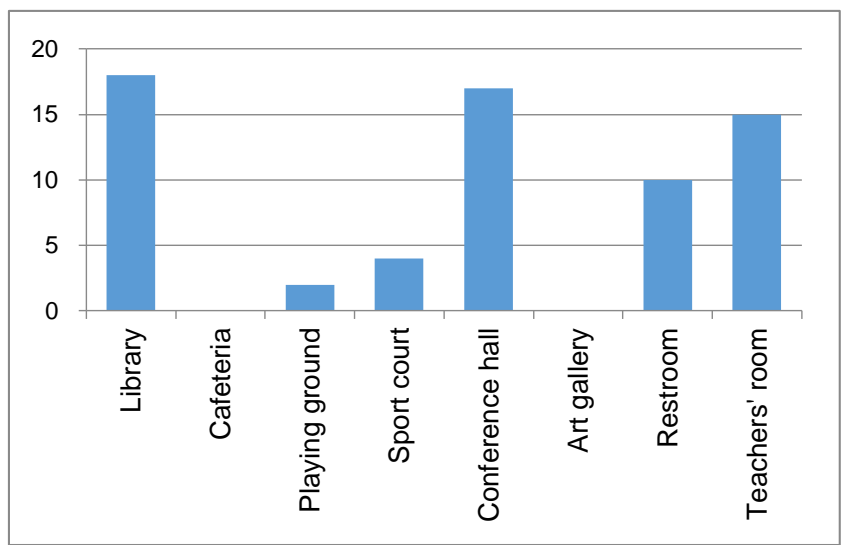

Chart 1. The frequency of existing school facilities (analysis result, 2017).

Chart 1 indicates that the schools lack spaces for free activity and creativity development of children (such as art workshops); on the other hand, the low frequency of playgrounds and sports courts suggests that the schools play a minor role in encouraging children to participate in sports activities. So, attention to spaces for children's leisure and sports games is preferable.

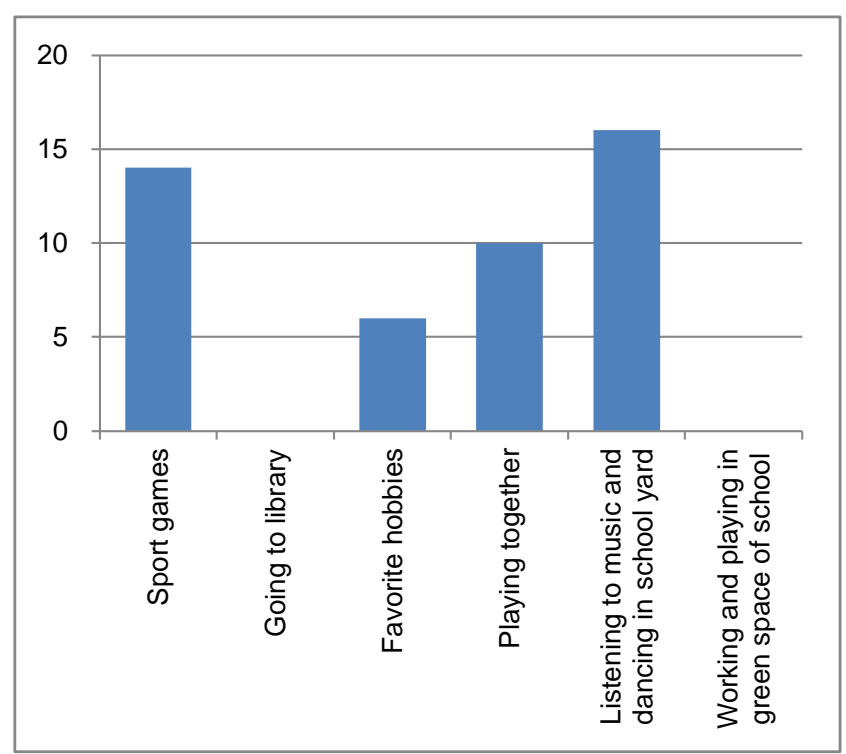

Chart 2. Children's leisure time in current schools (analysis result, 2017).

According to chart 2, the high percentage of time spent on playing together and the interest in music show the importance of the design of educationalrecreational space. Also, the lack of green spaces in schools for children's playing indicates that the impact of nature on the learning process of children is not noticed and must be a priority in design.

Chart 3 demonstrates that monochromatic spaces have the highest frequency, which indicates the effects of colours on the growth of children are neglected.

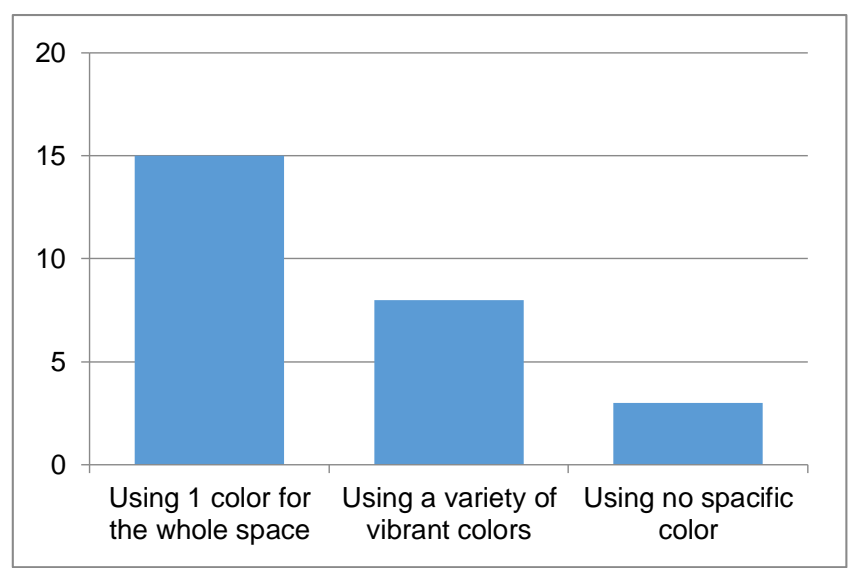

Chart 3. The frequency of colours in schools (analysis result, 2017).

According to Chart 4, the professional workshops, green spaces and interaction with nature, life skills training and colour diversity in the area are the most critical factors in designing an educational-recreational space for mentally disabled children, respectively.

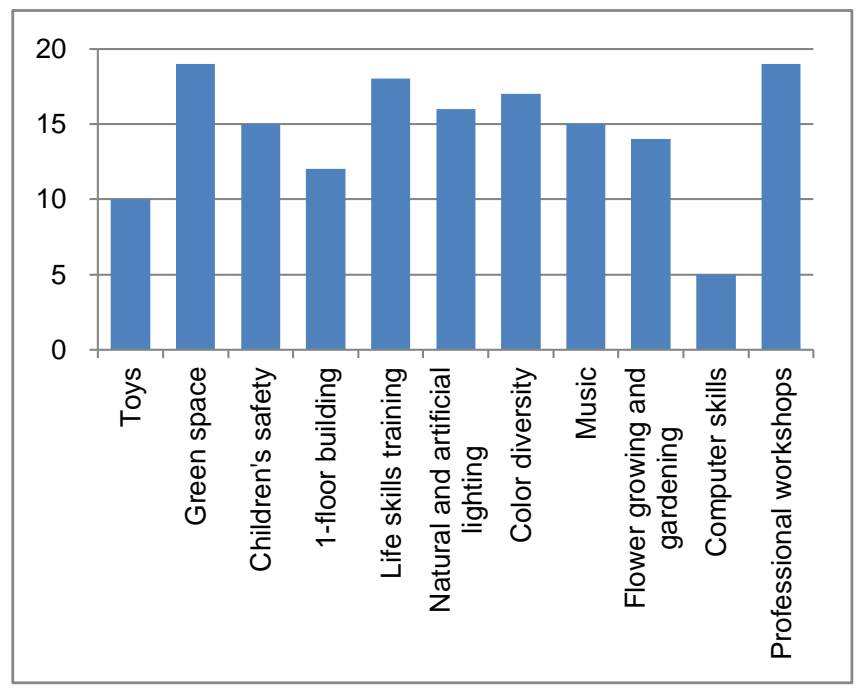

Chart 4. The frequency of educational-recreational spaces necessary factors for mentally disabled children (analysis result, 2017).

\subsection{Design Solutions}

Given the studies, field observations and parents' ideas, the following design solutions can be considered (see table 2). 
Table 2. Design solution recommendation

\begin{tabular}{lll}
\hline $\begin{array}{l}\text { Items derived } \\
\text { from library }\end{array}$ & $\begin{array}{l}\text { Positive points of } \\
\text { field observations } \\
\text { in internal case } \\
\text { research }\end{array}$ & $\begin{array}{l}\text { Design solutions } \\
\text { studies }\end{array}$
\end{tabular}

$\begin{array}{lll}\begin{array}{l}\text { A suitable } \\ \text { environment }\end{array} & \begin{array}{l}\text { Provision of a ramp } \\ \text { and a wheelchair }\end{array} & \begin{array}{l}\text { Construction of ramps to access various } \\ \text { levels }\end{array} \\ \begin{array}{l}\text { for the arrangement of } \\ \text { disabled }\end{array} & \begin{array}{l}\text { Provision of space for a wheelchair in } \\ \text { an elevator for the } \\ \text { disabled }\end{array} & \begin{array}{l}\text { elevators, bathrooms, playing areas, etc. } \\ \end{array}\end{array}$

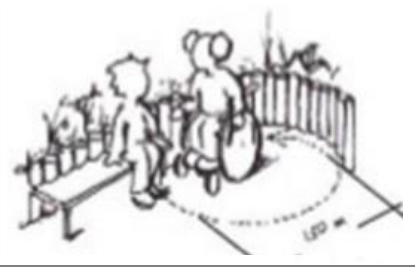

Attractive and friendly environment (stimulating elements in the atmosphere)

Children's wall paintings in corridors of Farshchian School
Attention to childish and decorative items in inside and outside spaces Provision of calm playing zones (sand play, water play, etc.)

The arrangement of visual playing zones (walls and floors for children's painting in playgrounds)
Individual and collective activities

\section{Social}

interaction

The interaction between inside and outside
Collective tables and furniture (radial layout) in Farshchian School
Different games and activities (cycling, cooking, etc.) Sports games (to gather children) Open plan and less use of solid walls in interior spaces

Transparent walls for the safety of little children

Provision of outdoor roofed spaces
Safety and security
Minimum use of stairs for access and installation of handrails for safety

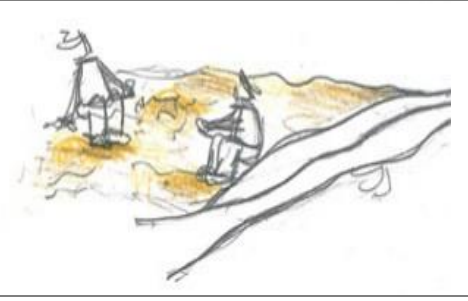




\begin{tabular}{|c|c|c|}
\hline $\begin{array}{l}\text { Items derived } \\
\text { from library } \\
\text { research }\end{array}$ & $\begin{array}{l}\text { Positive points of } \\
\text { field observations } \\
\text { in internal case } \\
\text { studies }\end{array}$ & Design solutions \\
\hline
\end{tabular}

Access to a variety of activities
Provision of different playing areas according to requirements of holistic development of children

Provision of suitable playing facilities and equipment for children
Readability and inviting feature of the environment
Design of access routes for different spaces (using textured floors, etc.)
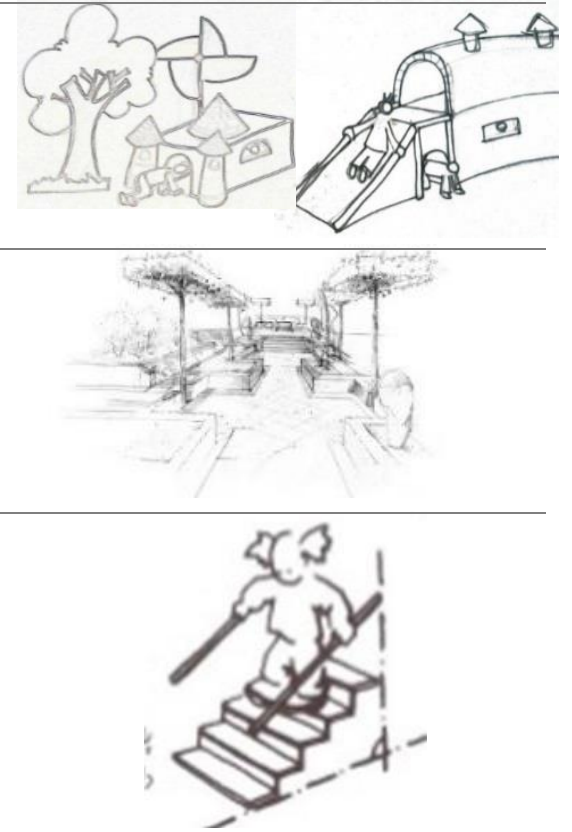

Source: analysis result, 2017

\section{CONCLUSION}

The research has determined the useful criteria used to design an attractive and friendly environment for mentally disabled children. In addition to promoting the sense of safety and security in these spaces, it improves recreational activities of mentally disabled children both individually and collectively.

\section{REFERENCE}

Abbasi, S., Fadakar Sougheh, K., Khalegh Doustmohammadi, T., Sediqi, A., \& Atrkar Roshan, Z. (2011). Study on economic problems of families with mentally disabled children covered by the Guilan Welfare Organization. Journal of Nursing and Midwifery Care, 2, 24-35.

Cabarcas, L., Espinosa, E., \& Velasco, H. (2013). Etiology of mental retardation in children: experience in two third level centers. Biomedica: revista del Instituto Nacional de Salud, 33(3), 402410. doi:10.7705/biomedica.v33i3.785

Ganji, M. (2013). Psychological pathology based on DSM-IV. Tehran. Savalan Publications, 2(592).

Lang, J. T. (1987). Creating Architectural Theory: The Role of the Behavioral Sciences in Environmental Design. Van Nostrand Reinhold Company.

M Alagheband, AAghayousefi, M, K., M, D., F, H., T, N., \& M.h, S. (2011). Effect of Coping-Therapy on Mental Health of Mothers With Genetic and NonGenetic Mentally Retarded Children. Journal of
Shahid Sadoughi University of Medical Sciences and Health Services, 19(176), 104-113.

Mostafa, M. (2008). An Architecture For Autism: Concepts of Design Intervention For The Autistic User. International Journal of Architectural Research: ArchNet-IJAR, 2(1), 189-211. doi:10.26687/archnet-ijar.v2i1.182

Tabaian, S. M. (2014). Human and environment (psychological approach to architecture and urbanism). Islamic Azad University of Isfahan (Khorasgan).

Tabaian, S. M., Nikravesh, R., \& Abduli, S. (2015). The Architecture of educational spaces for children with special needs. Islamic Azad University of Isfahan (Khorasgan).

Vargo, F. E. (2015). Neurodevelopmental Disorders: A Definitive Guide for Educators. W. W. Norton \& Company. 